\title{
SINGLE-GRAIN OPTICALLY STIMULATED LUMINESCENCE AGES OF BROWNWARE POTTERY IN THE MIDDLE ROCKY MOUNTAINS AND THE SPREAD OF NUMIC CERAMIC TECHNOLOGY
}

\author{
Judson Byrd Finley, Carlie J. Ideker, and Tammy Rittenour
}

\begin{abstract}
This study presents the results of a single-grain optically stimulated luminescence (SG-OSL) analysis of brownware pottery from four Late Prehistoric-period sites in the Middle Rocky Mountains, Wyoming, USA. SG-OSL of quartz ceramic temper provides improved age control for sites where radiocarbon dating has proven problematic due to old wood, recent wildfires, and calibration uncertainties. SG-OSL results are compared to fine-grain infrared stimulated luminescence (FG-IRSL) results from the same sherds and associated radiocarbon ages. We find that the single-grain technique applied to quartz sand temper provides improved accuracy and precision over both FG-IRSL and radiocarbon. We compare our results to directly dated brownwares from the southern and eastern Great Basin based largely on thermoluminescence analysis. While brownware ceramics appear earliest in the southwestern Great Basin, our data show that the technology spread quickly to the northeastern margin of the Numic homelands. We suggest that knowledge of ceramic technology in Formative (i.e., Ancestral Pueblo and Fremont) societies was important in the adoption of pottery by Numic hunter-gatherers and that, like in the southwestern Great Basin, this technological adaptation in the Middle Rocky Mountains may have occurred within a context of resource intensification during the last 800 years.
\end{abstract}

Este trabajo presenta los resultados de un análisis de luminiscencia ópticamente estimulada de grano único (SG-OSL) de la cerámica café procedente de cuatro sitios del período prehistórico tardío en las Montañas Rocosas centrales, Wyoming, Estados Unidos. El análisis SG-OSL de cuarzo usado como desgrasante en la cerámica proporciona un mejor control cronológico para sitios donde la datación por radiocarbono ha resultado problemática debido a madera vieja, incendios recientes e incertidumbres de calibración. Se comparan los resultados del análisis SG-OSL con los de la luminiscencia estimulada por infrarrojo de grano fino (FG-IRSL) de los mismos tiestos y con las edades de radiocarbono asociadas. Encontramos que la técnica de grano único aplicada al desgrasante de arena de cuarzo proporciona mayor precisión y exactitud que el FG-IRSL y el radiocarbono. Comparamos nuestros resultados con muestras directamente datadas de cerámica café procedentes de la Gran Cuenca meridional y oriental principalmente con base en el análisis por termoluminiscencia. Mientras que la cerámica café aparece antes en el suroeste de la Gran Cuenca, nuestros datos muestran que la tecnología se extendió rápidamente al margen noreste del territorio de origen de la gente de habla Numic. Sugerimos que el conocimiento de la tecnología cerámica en las sociedades formativas (es decir, Pueblo ancestral y Fremont) fue importante en la adopción de cerámica por los cazadores-recolectores númicos y que, al igual que en la Gran Cuenca del suroeste, esta adaptación tecnológica en las Montañas Rocosas centrales podría haber ocurrido en un contexto de intensificación de recursos durante los últimos 800 años.

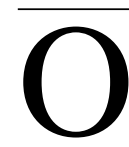
ver the last two decades, the Middle Rocky Mountains (MRM) have emerged as an important area in western North American archaeological research. More than a century of fire suppression, combined with major regional drought and insect infestation, has devastated western forests, making large wildland fires a common part of the summer season. Many fires occur within the vast, highelevation wilderness areas that until recently saw little archaeological research. Archaeological surveys have identified occupations at

Judson Byrd Finley $\square$ Department of Sociology, Social Work, and Anthropology, Utah State University, 0730 Old Main Hill, Logan, Utah 84322-0730, USA (judson.finley@usu.edu, corresponding author)

Carlie J. Ideker $\square$ Department of Sociology, Social Work, and Anthropology and Luminescence Laboratory, Utah State University, 0730 Old Main Hill, Logan, Utah 84322-0730, USA (carlie.ideker@usu.edu)

Tammy Rittenour $\square$ Department of Geology and Luminescence Laboratory, Utah State University, 4505 Old Main Hill, Logan, Utah 84322-4505, USA (tammy.rittenour@usu.edu) 
high-elevation sites extending into the terminal Pleistocene and early Holocene, but the extensive Late Prehistoric to Historic record (ca. $<1500$ cal BP; Kornfeld et al. 2010) calls into question the role of alpine environments in regional subsistence and settlement patterns. Of particular interest are "villages" at or above 3,000 m asl associated with a broad spectrum resource base that includes bighorn sheep, whitebark pine nuts, and roots. The MRM record draws parallels to a larger pattern of high-elevation occupation and resource intensification throughout the Great Basin during this time (Bettinger 1991; Morgan, Fisher, and Pomerleau 2012; Thomas 2014).

Obtaining age control from high-elevation archaeological sites with radiocarbon has proven a challenge due to an old-wood problem common near the upper treeline and the release of carbon into archaeological sites during wildfires. However, because many of these sites are associated with ancestral Numic occupations, brownware pottery is common in material assemblages and provides an opportunity for additional chronological control by directly dating the manufacturing age of pottery with singlegrain optically stimulated luminescence (SGOSL). We applied SG-OSL dating to the quartz sand temper of 10 pottery samples from four archaeological sites located in the Wind River and Absaroka Ranges (Figure 1). The detailed protocol and performance characteristics of the pottery samples using this dating technique are presented elsewhere (Ideker 2016; Ideker et al. 2017); here, we summarize those methods and demonstrate the validity of the technique in archaeological contexts. We selected samples of brownware pottery sherds from sites with comparable radiocarbon ages. In addition to SG-OSL, we dated each sherd using fine-grain infrared stimulated luminescence (FG-IRSL; Feathers 2008, 2009). Our results suggest that SG-OSL provides improved age control compared to both radiocarbon and FG-IRSL because uncertainties between dated and target events are reduced in the case of radiocarbon, and age distributions are more precise due to the elimination of signal fading anomalies in FG-IRSL.

Because relatively little is known about regional brownware pottery, our second objective is to evaluate the spread of brownware pottery technology into the MRM, the northeastern margin of the vast Numic homeland. We place our results within a context of directly dated Formative (i.e., Ancestral Pueblo and Fremont) and brownware pottery from the southern and eastern Great Basin (EGB) (Eerkens and Lipo 2014; Feathers and Rhode 1998; Reed 2005; Rhode 1994). This work demonstrates that brownwares appeared earliest in the southern Great Basin (SGB) approximately 1,200 years ago, where ages overlap with Ancestral Pueblo pottery. Direct age control on pottery from the EGB and MRM show the near simultaneous appearance of brownware in both regions 800 years ago. We suggest that this process of technological diffusion occurred within a broader context of foragerfarmer interactions, particularly among Fremont communities in the Great Salt Lake and Uinta Basin regions of northern Utah (Madsen and Simms 1998; Upham 1994). Significantly, we argue that brownware technology quickly grafted onto a "Desert culture" population base (Upham 1994:124) with Numic roots that extended into the MRM for centuries, if not millennia. While our sample size is small and there is still much to learn about the use of brownware pottery among regional foragers, we suggest that the adoption of pottery by the ancestral Numa of the MRM was a technological component of a trend toward resource intensification observed throughout western North America during the last 1,500 years. Here we develop a regional context for brownware studies, review luminescence dating methods applied to pottery, and summarize the results of our analysis. We conclude by discussing the implications of a brownware chronology in western North American archaeology.

\section{Brownware Studies in Western North America}

By the mid-twentieth century, archaeologists recognized three primary brownware types across interior western North America: Southern Paiute Utility Ware, Owens Valley Brown Ware, and Shoshone or Intermountain Ware (Madsen 1986; Pippin 1986). As Eerkens and others (2002:203) note, many researchers cite inconsistency in identifying key attributes for the failed 


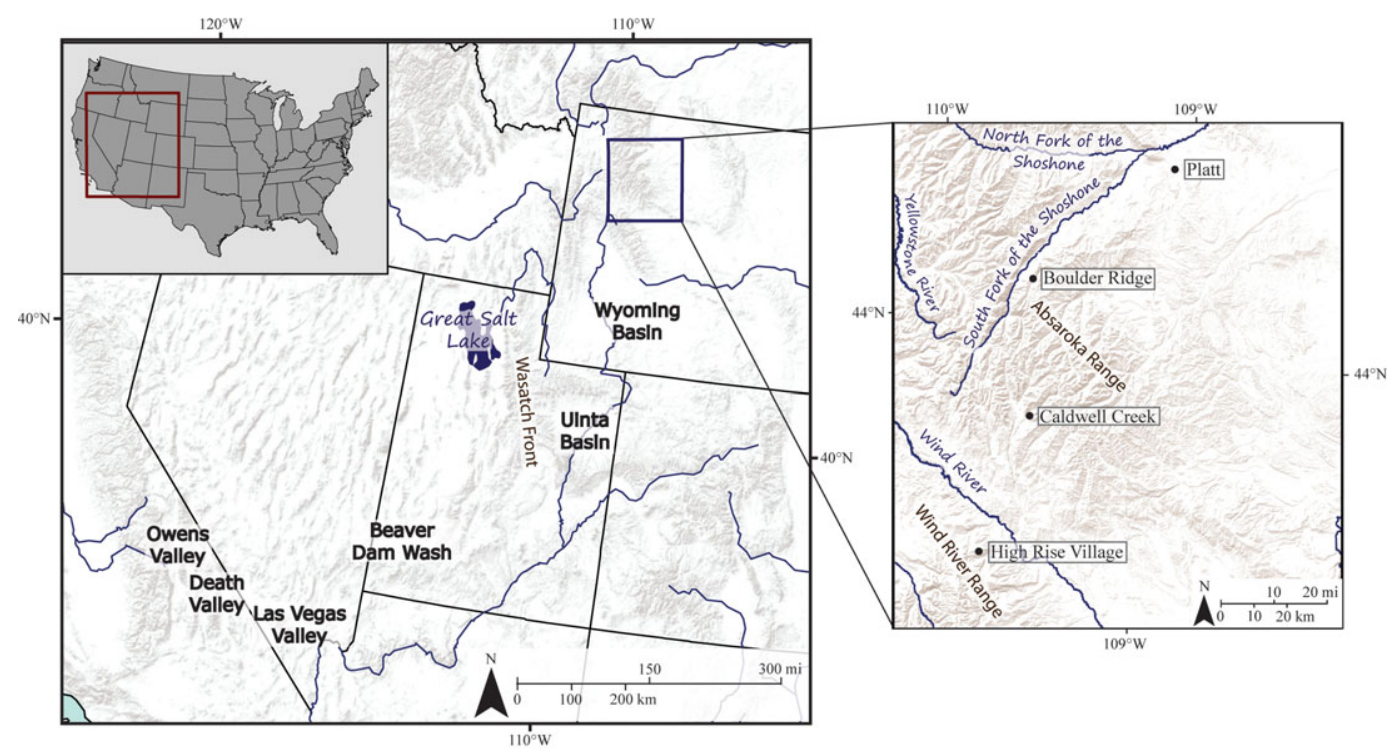

Figure 1. Location of the study area showing the sites sampled for single-grain OSL analysis and the regions compared for direct dates on brownwares. (Color online)

development and use of brownware typologies (Dean 1992). Eerkens and others (2002) suggest that geochemical and mineralogical analyses provide the most reliable and replicable typologies in the western Great Basin, a technique that Finley and Scheiber (2010) verified in the Wyoming Basin and MRM. Coale (1963) provided the most consistent, cohesive, and regionally applicable description of brownware ceramics. Vessels were made using coiling and scraping and molding techniques. They have flat bottoms, relatively straight but thick walls with direct to slightly curved rims, and surface decoration usually limited to fingernail impressions or geometric patterns near the rim. Vessels are often coarsely tempered, although grain size varies with locally available sands. Brownware chronology is poorly developed, and the style is generally thought to be less than 600 years old throughout the majority of the Numic homelands (Butler 1986; Eerkens 2003; Pippin 1986; Wright 1978). Direct thermoluminescence (TL) and optically stimulated luminescence (OSL) dating of brownwares indicate that Numic foragers experimented with ceramic technology early throughout interior western North America, and age-overlaps between both Ancestral Pueblo and Fremont traditions challenge the interpretation of a more recent Numic adoption of ceramic technology (Eerkens and Lipo 2014; Feathers and Rhode 1998; Ideker et al. 2017; Rhode 1994). We discuss regional age relationships in more detail below.

\section{Brownware Ceramics and Social Dynamics in the Western Great Basin}

The ethnography and archaeology of the western Great Basin are fertile ground for problemoriented and theoretically informed research (Eerkens 2003, 2004, 2005; Eerkens et al. 2002; Eerkens and Lipo 2011, 2014). Steward's (1933) Owens Valley Paiute ethnography poses an interesting scenario of Great Basin huntergatherer social and technological organization, namely those of brownware craft specialization, resource ownership, and a pseudo-market economy among Paiute women. Eerkens and others (2002:201-203) position this problem as one of an economy of scale, noting that ceramic specialization should be rare in hunter-gatherer societies given the inherent conflict between the time demands of pottery production and mobility requirements for foraging. They propose that Paiute women solved this problem by pooling resources; certain "enterprising" women overproduced and exchanged pottery for either shell 
money or food. Following this logic, brownware pottery should be produced in core areas where ceramics specialists controlled access to clay and temper and traded throughout the region. Eerkens and others (2002) tested this hypothesis with a neutron activation analysis of clay elemental composition of both archaeological sherd and geological clay sources from 380 samples. They found that, while regionally discrete source areas were evident, the sample did not support Steward's model of craft specialization and trade. Instead, environmental parameters, namely precipitation in these arid western basins, structured the movement of people and pottery.

Eerkens (2004) evaluated a second assertion of Steward's (1933) ethnographic research that makes western Great Basin foragers unique among similar societies, namely that of resource ownership or privatization of small, herbaceous seeds. Multiple lines of evidence support the role of brownware ceramics in the privatization of small seeds during the Marana period $(600 \mathrm{cal} \mathrm{BP}$ to contact). Most important are the co-occurrence of ceramics and ground stone on archaeological sites, direct rim vessels consistent with making soups or gruels, and chemical analysis of food residues suggesting they were dominated by seeds (Eerkens 2004:657-659). In addressing the question of why hunter-gatherers should adopt ceramic technology in the first place, Eerkens (2004:661-663) asserts that it increases efficiency in a context of resource intensification focused on small seeds. Unlike hunted meat (either individual kills of large game or rabbits trapped en masse), seeds are not widely shared among hunter-gatherer families. Since seeds can be simmered over small fires, they are also not like roots and tubers that require roasting in large, visible, stone-filled pits. Ceramics, then, are part of privately owned technologies that allowed women to cook food for their families, thus solving the problem of "freeloaders" reducing individual gains to families with children. In this case, archaeological analysis supports Steward's (1933) assertions of resource privatization among western Great Basin hunter-gatherers.

Most recently, Eerkens and Lipo (2014) use a luminescence geochronology of brownwares to test a diffusion model of design features across four subareas of the western Great Basin.
They suggest that a diffusion-based adoption of any technology takes the form of a temporally S-shaped distribution curve characterized by innovators, the "mainstream," and laggards. A number of factors that include availability of alternative technologies, the degree to which people rely on those alternatives, and the mode of cultural transmission determine the speed of adoption. Eerkens and Lipo (2014:25-26) predict that the adoption of brownware technology should follow the standard S-shaped curve, that adoption and diffusion should occur relatively slowly, and that experimentation will last longer in areas with the oldest exposure. Based on a sample of 167 luminescence ages coupled with changes in rim form, they suggest that direct rim forms diffused out of southern Owens Valley approximately 500 years ago after several centuries of experimentation. While there is no difference in ages between chronologies from Death Valley and China Lake, both areas have different shapes of temporal adoption curves than southern Owens Valley due to the extended period of experimentation in the latter. Finally, Eerkens and Lipo (2014:29) conclude that curved rims represent a failed innovation that originated somewhere east of Death Valley, perhaps near the present location of the Nevada Test Site. The most significant assertion this transmission model makes for our work in the MRM lies in the third prediction, that of the duration of a period of experimentation. We suggest that rather than a focal point of innovation in the southwestern Great Basin and relatively slow transmission from there, diffusion and adoption occurred rapidly across the interior of western North America.

\section{Brownwares in the Mountain World of the Numa}

In contrast with the western Great Basin, we know much less about ceramics in the social and technological organization of MRM huntergatherers. Regional ethnographies are not as well developed, but the lack of knowledge is also due to the paucity of brownware ceramics in the archaeological record. In a records search of 11 western Wyoming counties and Yellowstone National Park, which form the core of the MRM, Finley and Boyle (2014) found 209 sites containing ceramics totaling 6,175 sherds. On 
average, western Wyoming archaeological sites have fewer than 30 sherds, and more than $65 \%$ of sites have fewer than 10 sherds. Brownwares are reported from only 69 sites. Major regional ceramic sites include Eden-Farson (Frison 1971), a multi-house campsite associated with a communal pronghorn kill dated to $150-630 \mathrm{cal}$ $\mathrm{BP}$, and Bugas-Holding, a winter campsite and bighorn sheep butchering area dated to approximately AD 1500 (Kornfeld et al. 2010). Haspel (1984) described brownware ceramics from four Wyoming assemblages that share the same essential attributes as Great Basin brownwares: flat bottoms, straight but thick walls, direct to curved rims, and coarse temper. A poorly standardized regional typology is a major classification problem, and like western Great Basin studies, geochemical and mineralogical typologies are the most reliable and replicable approach (Finley and Scheiber 2010). Recently, the AD 2011 Norton Point wildfire in the Absaroka Range north of Dubois, Wyoming, exposed a major Shoshone occupation with more than 2,000 brownware sherds (Scheiber et al. 2014). Because we know so little, a few new finds in the MRM can dramatically change our ability to understand how brownwares were used in mountain-oriented subsistence strategies.

The major focus of brownware research in the MRM comes from their association with archaeological sites near or above 3,000 m asl. Brownware ceramics are found in low numbers in the Wind River Range of Wyoming and are assumed to have served as vessels for stewing bighorn sheep meat along with whitebark pine nuts and biscuitroot (Adams 2010; Morgan, Losey, and Adams 2012). In the Absaroka Range, archaeologists have used brownwares to explore issues of identity, continuity of craft technologies, and mobility as resistance within a context of eighteenth- and nineteenth-century culture contact (Scheiber and Finley 2010, 2011a). Finley and Scheiber (2010) conducted the only geochemical and mineralogical compositional analysis to date. Their pilot study examined sherds from four sites in the Wyoming Basin and Absaroka Range to explore social interactions between resident Kukundika (i.e., Buffalo Eaters) and Tukudika (i.e., Sheep Eaters) bands, who occupied the two areas at contact (Hoebel
1938). While brownwares in these geologically distinct areas form discrete chemical and mineralogical groups, they show no evidence of pottery or people moving far beyond their source areas, a conclusion that supports recent regional syntheses of obsidian source analysis (Finley et al. 2015; Scheiber and Finley 2011b). As part of a brownware materials characterization study, Ideker (2016) and Ideker and colleagues (2017) applied principles of SG-OSL to brownwares from several of these sites. Here we report the methods and results of this work, along with the implications of an expanded brownware chronology for the adoption of ceramic technology in the MRM.

\section{Ceramics Luminescence Geochronology}

Luminescence dating has been widely applied to archaeological ceramics (Aitken 1985, 1997; Feathers 2003, 2008, 2009; Lipo et al. 2005). Luminescence dating operates on the fundamental principle that emissions from common radioactive isotopes such as ${ }^{40} \mathrm{~K},{ }^{238} \mathrm{U}$, and ${ }^{232} \mathrm{Th}$ interact with other elements, knocking electrons from their orbits and into positively charged defects or "traps" in the crystalline structure of quartz and feldspar minerals. Exposure to either heat or light releases those trapped electrons that emit photons as they shift energy bands; this emission is the luminescence signal (Huntley et al. 1985). The strength of the luminescence signal (known as the natural signal) is proportional to the length of time over which the crystal has trapped electrons (known as the sample age), and the radioactivity of the local environment (known as the dose rate or $D_{R}$ ). In the laboratory, the natural signal is measured and replicated through exposure to radiation from a controlled source to calculate the equivalent dose or $\mathrm{D}_{\mathrm{E}}$. Dose rate is determined by either directly measuring radioactive emissions or quantifying concentrations of radioactive minerals in the local environment plus an estimated cosmic contribution. Age is a function of equivalent dose divided by dose rate. The luminescence signal is reset or considered "bleached" upon sufficient exposure to either heat or light. Luminescence analysis is typically carried out on very fine to fine-grained quartz and feldspar sand (e.g., within the $250-63 \mu \mathrm{m}$ range) 
or very fine-grained mixed mineral (polymineral) silt (11-4 $\mu \mathrm{m})$.

Luminescence dating employs either multiple or single aliquot techniques, with each aliquot containing tens to thousands of grains or single grains of isolated quartz or feldspar. The latest generation single-aliquot regenerativedose (SAR) technique (Murray and Wintle 2000) reduces error from inter-aliquot variability by monitoring and correcting for sensitivity changes induced by repeated exposure to ionizing radiation to determine the equivalent dose. In many ways, single-grain analysis is the leading edge of OSL dating, as it allows a grain-by-grain consideration of luminescence properties and individual $\mathrm{D}_{\mathrm{E}}$ estimates when calculating the final age (Duller 2008; Rittenour et al. 2015).

Archaeological ceramics are unique but complicated chronometers. Measurements can be made on the coarse mineral temper component, ideally quartz or feldspar fine sand $(250-63 \mu \mathrm{m})$ or the polymineral very fine silt $(11-4 \mu \mathrm{m})$ paste (Aitken 1985; Feathers 2009). Dose rate contributions are both from external sources, coming from the natural environment, and internally derived from the mineral constituents of the sherd itself. Environmental contributions of alpha and beta radiation are minimized in ceramic analysis by removing the outer two millimeters of the sherd and focusing on the innermost material. The dominant remaining dose rate contributions are long-range gamma radiation from the sherd and surrounding sediments and short-range alpha and beta radiation natural to the sherd mineralogy (Feathers 2009:121). Thus, it is important in ceramic analysis to have accompanying sediment samples within an approximately $30 \mathrm{~cm}$ radius of the sherd to accurately measure the environmental dose rate (Nelson et al. 2015). Heat, or thermoluminescence (TL), has been the preferred method for releasing stored charges, although OSL is becoming more common due to advances in the SAR protocol.

In the case of ceramics, analysts commonly measure the luminescence signal of the polymineral fine fraction $(11-4 \mu \mathrm{m})$ from the ceramic paste due to the lack of coarse minerals in most ceramics (Feathers 2003, 2009; Forget Brisson et al. 2015; Lipo et al. 2005). Polymineral fine-grain luminescence uses either infrared stimulated luminescence (FG-IRSL) to measure feldspar signals or post-IR blue OSL to measure quartz signals by bleaching feldspar grains prior to measuring the luminescence signal (Banerjee et al. 2001). With IRSL, anomalous fading, or the loss of the natural signal over time in feldspar minerals, must be determined and corrected to avoid underestimates in final age calculations. In addition to potential complications with anomalous fading, signal contributions from minerals other than quartz and feldspar increase uncertainties in polymineral fine-grain dating of ceramic paste. We applied SG-OSL dating of quartz temper and reported the performance characteristics of the results against polymineral FG-IRSL results (Ideker 2016; Ideker et al. 2017). We review the results and findings here.

\section{Single-Grain OSL of Brownware Ceramics}

We selected brownware samples from four northwestern Wyoming archaeological sites to apply single-grain dating to the quartz ceramic temper (Ideker et al. 2017): High Rise Village, Boulder Ridge, Caldwell Creek, and the Platt site (Figure 1). High Rise Village is a large, late Prehistoric campsite above $3,050 \mathrm{~m}$ asl in the Wind River Range with numerous habitation features and artifact assemblages indicating a diverse subsistence strategy focused on a combination of bighorn sheep hunting and harvesting of whitebark pine nuts and lomatium roots (Morgan, Losey, and Adams 2012). The Boulder Ridge site lies just below $3,050 \mathrm{~m}$ asl in the Absaroka Range and is a large campsite spanning the terminal Late Prehistoric and Historic periods (Eakin 2005; Scheiber and Finley 2010, 2011a). Occupations at Boulder Ridge centered on two bighorn sheep communal hunting traps, and while evidence for only two lodges was present, artifact and bone distributions indicate a spatially extensive campsite. The Caldwell Creek site is a relatively recent discovery (Scheiber et al. 2014) and is one of the largest known Late Prehistoric campsites in the Absaroka Range. Finally, the Platt site, in the foothills of the Absaroka Range near Cody, Wyoming (Platt and Hughes 1986), contains a long Holocene archaeological record, but a buried Late Prehistoric component is most important to this study. All sites except the Platt 
site have experienced extensive wildfires at some point in their recent histories (i.e., AD 2003 in the case of Boulder Ridge and AD 2011 at Caldwell Creek). Each of the sites also has brownware pottery as part of the Late Prehistoric material assemblages. The pottery comes from excavated contexts at High Rise Village, Caldwell Creek, and the Platt site. The Boulder Ridge samples are from the surface. As we show below, burial context is an important issue that potentially offsets resetting of luminescence signals during wildfires.

The sampled brownwares (Figure 2) are ideal because they have abundant sandy quartz temper, and the SG-OSL protocol can help interpret or resolve age control of potentially problematic radiocarbon chronologies. These problems are chiefly due to the presence and preservation of ancient trees near the sites that may have been incorporated into structural timbers and fire hearths (i.e., the "old wood problem" [Schiffer 1986]) and the occurrence of recent wildfires that released modern charcoal at the sites. While our focus is on producing SG-OSL ages from the quartz temper, we also analyzed the paste of the same sherds dated with SG-OSL using a modified polymineral FG-IRSL protocol (Banerjee et al. 2001; Wallinga et al. 2000) with correction for fading (Auclair et al. 2003). Results from both methods were within error. Samples from Boulder Ridge returned near-zero ages, presumably due to exposure to an AD 2003 wildfire. In all, our results provide additional chronological control for each site and validate further application of the SG-OSL method for regional ceramic geochronology.

The SG-OSL Protocol. All samples were processed and analyzed at the Utah State University (USU) Luminescence Laboratory in Logan, Utah. Working under dim amber light conditions, lab personnel removed the outer $2 \mathrm{~mm}$ of each sherd to eliminate grains that may have been reset from exposure to heat or light and to simplify the dose rate calculation by removing grains exposed to short-wave alpha and beta radiation from the external environment. The inner core of the sherd was gently disaggregated and the 250-63 $\mu \mathrm{m}$ quartz fraction was isolated using hydrochloric acid and chlorine bleach to remove the carbon- ate and organic fractions, sodium polytungstate $\left(2.7 \mathrm{~cm} / \mathrm{gm}^{3}\right)$ to remove heavy minerals, and hydrofluoric acid to remove feldspars and etch quartz grains (Rittenour et al. 2005, 2015).

Because ceramics receive radiation from external and internal sources, dose rate calculations were made from associated sediment samples and a subsample of the sherd itself. Radioactive elemental concentrations were measured directly using inductively coupled plasma mass spectrometry (ICP-MS). Cosmic contributions for each sample were estimated using the latitude and elevation of each site and the sample depth (Prescott and Hutton 1995). Isolated quartz grains were analyzed on a Risø TL/OSL Model DA-20 Reader with a single-grain attachment and Ris $\varnothing$ single-grain disks (300 $\mu \mathrm{m}$ hole openings, 1-3 grains per hole) following the SAR protocol with $200^{\circ} \mathrm{C}$ and $160^{\circ} \mathrm{C}$ preheat treatments following regenerative and test dose steps, each held for 10 seconds (Ideker et al. 2017). Four hundred to 1,200 grains were analyzed from each sample, and at least 77 grains passed rejection criteria and returned equivalent dose values for age calculations. The reported ages were calculated using an unlogged central age model (CAMUL, Galbraith and Roberts 2012) and are reported with two-sigma standard errors. Ages are reported in calendar years using AD 2010 as the reference point. All radiocarbon ages were calibrated using the IntCal13 calibration curve (Reimer et al. 2013), are reported at twosigma error and, in addition to their conventional ages, in years before AD 2010, rather than the standard AD 1950 used in radiocarbon dating, to allow direct comparison to the OSL results.

OSL Age Results. Eight of 10 sherds submitted for analysis returned OSL ages indicating either the age of vessel manufacture or the last firing (heating) event (Table 1). Two sherds, one from High Rise Village and one from the Caldwell Creek site, were too small to yield enough material for analysis, suggesting in this case a minimum size for analysis of approximately 18 $\times 15 \times 9 \mathrm{~mm}$. Three sherds from the surface of Boulder Ridge returned SG-OSL ages of $18 \pm$ $16 \mathrm{yr}$ (USU-1571), $34 \pm 27 \mathrm{yr}$ (USU-1586), and $23 \pm 19$ yr (USU-1769) (Table 1). These nearzero ages are consistent with a recent resetting of 


\section{Boulder Ridge}
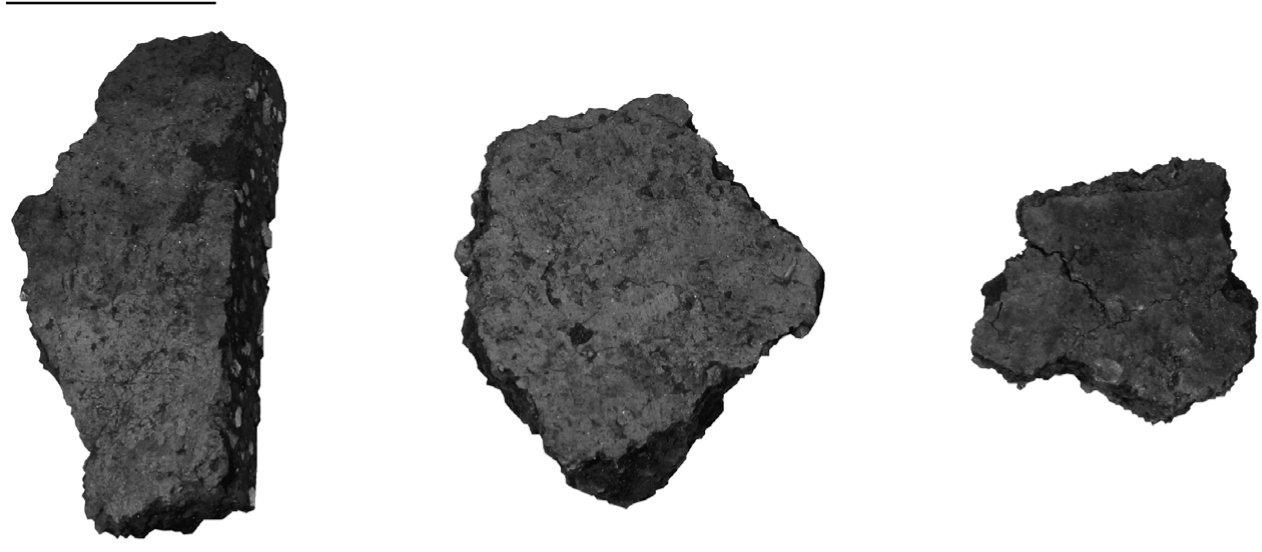

High Rise Village
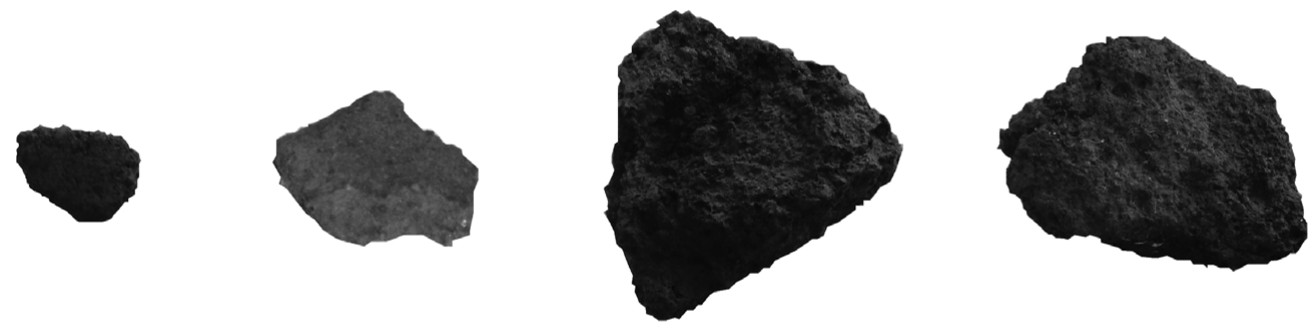

Caldwell Creek

Platt
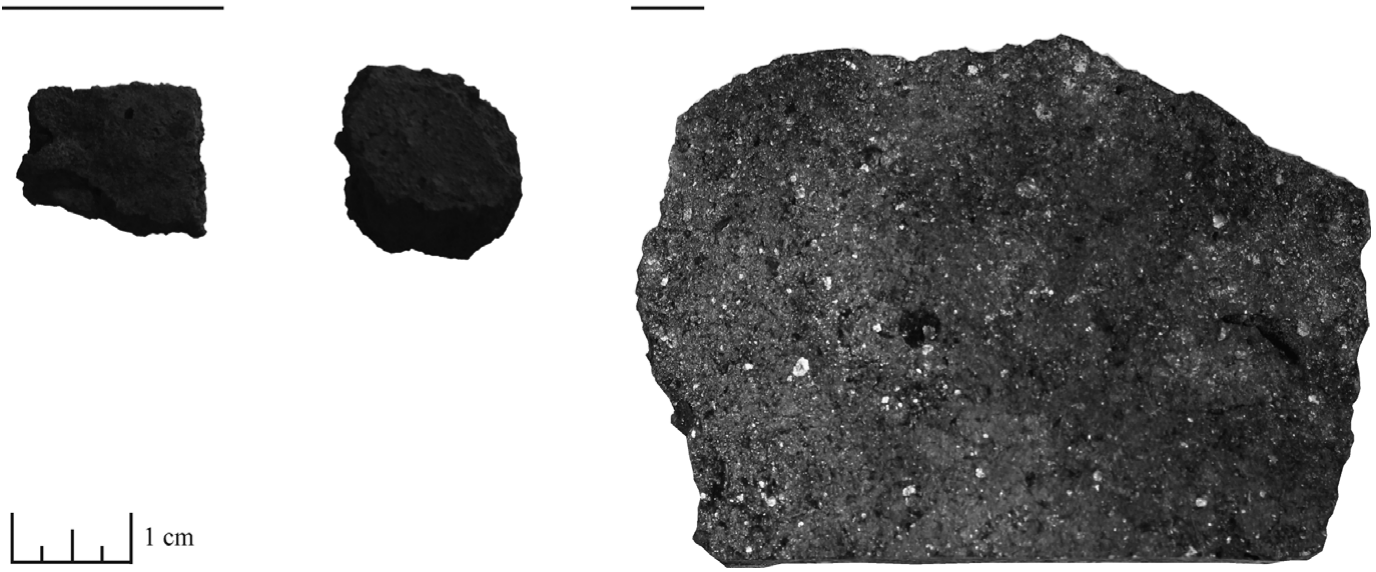

Figure 2. The 10 brownware sherds from Boulder Ridge, High Rise Village, Caldwell Creek, and the Platt site prior to analysis.

the luminescence signal indicating that the sherds were impacted by the AD 2003 Boulder Basin II wildfire. The wildfire did not reset the luminescence signal of all grains, however, and the mean of the upper $25 \%$ of the single-grain $\mathrm{D}_{\mathrm{E}}$ data from the Boulder Ridge sherds produces apparent maximum ages of $130 \pm 40 \mathrm{yr}$ to $280 \pm 80 \mathrm{yr}$. If these grains represent a sample of the population that was not reset during the fire, then they potentially estimate the vessel manufacture date. 
Table 1. Luminescence Results from Quartz Temper and Polymineral Paste.

\begin{tabular}{|c|c|c|c|c|c|c|c|}
\hline $\begin{array}{l}\text { USU lab } \\
\text { number }\end{array}$ & Site & Analysis $^{\mathrm{a}}$ & $\begin{array}{c}\text { Number } \\
\text { of } \\
\text { grains/ } \\
\text { disks }{ }^{b}\end{array}$ & $\begin{array}{c}\text { Equivalent } \\
\text { dose }^{c} \\
(\mathrm{~Gy})\end{array}$ & $\begin{array}{c}\text { Dose } \\
\text { rate }^{\mathrm{d}} \\
(\mathrm{Gy} / \mathrm{ka})\end{array}$ & $\begin{array}{c}\text { Fading } \\
\text { Rate } \\
\text { (gadays } \% / \\
\text { decade) }\end{array}$ & $\begin{array}{c}\text { OSL/ } \\
\text { IRSL } \\
\text { age }^{\mathrm{e}} \\
(\mathrm{yr}) \pm 2 \sigma\end{array}$ \\
\hline \multirow[t]{2}{*}{ USU-1571 } & \multirow[t]{2}{*}{ Boulder Ridge } & SG-OSL & $152(1100)$ & $0.06 \pm 0.05^{\mathrm{f}}$ & $3.14 \pm 0.13$ & & $18 \pm 16$ \\
\hline & & FG-IRSL & $9(21)$ & $0.21 \pm 0.28^{\mathrm{f}}$ & $4.72 \pm 0.30$ & $3.9 \pm 0.6$ & $50 \pm 70$ \\
\hline \multirow[t]{2}{*}{ USU-1586 } & \multirow[t]{2}{*}{ Boulder Ridge } & SG-OSL & $136(1200)$ & $0.10 \pm 0.08^{\mathrm{f}}$ & $2.98 \pm 0.12$ & & $34 \pm 27$ \\
\hline & & FG-IRSL & $9(14)$ & $0.22 \pm 0.17^{\mathrm{f}}$ & $4.08 \pm 0.27$ & $3.9 \pm 0.6$ & $60 \pm 50$ \\
\hline \multirow[t]{2}{*}{ USU-1769 } & \multirow[t]{2}{*}{ Boulder Ridge } & SG-OSL & $183(600)$ & $0.08 \pm 0.07^{\mathrm{f}}$ & $3.49 \pm 0.20$ & & $23 \pm 19$ \\
\hline & & FG-IRSL & $9(20)$ & $0.32 \pm 0.37^{\mathrm{f}}$ & $4.81 \pm 0.33$ & $3.9 \pm 0.6$ & $80 \pm 90$ \\
\hline \multirow[t]{2}{*}{ USU-1781 } & \multirow[t]{2}{*}{ HRV Lodge S } & SG-OSL & $314(600)$ & $2.11 \pm 0.12$ & $3.11 \pm 0.13$ & & $680 \pm 70$ \\
\hline & & FG-IRSL & $17(25)$ & $2.11 \pm 0.57$ & $4.65 \pm 0.31$ & $4.0 \pm 0.8$ & $580 \pm 140$ \\
\hline \multirow[t]{2}{*}{ USU-1782 } & \multirow[t]{2}{*}{ HRV Lodge CC } & SG-OSL & 77 (400) & $2.28 \pm 0.31$ & $4.27 \pm 0.29$ & & $530 \pm 90$ \\
\hline & & FG-IRSL & $23(27)$ & $3.28 \pm 0.74$ & $6.72 \pm 0.49$ & $3.6 \pm 0.7$ & $660 \pm 160$ \\
\hline \multirow[t]{2}{*}{ USU-1783 } & \multirow[t]{2}{*}{ HRV Lodge CC } & SG-OSL & $138(500)$ & $2.27 \pm 0.19$ & $4.38 \pm 0.34$ & & $520 \pm 70$ \\
\hline & & FG-IRSL & $13(15)$ & $2.19 \pm 0.69$ & $7.14 \pm 0.53$ & $3.2 \pm 0.6$ & $410 \pm 140$ \\
\hline \multirow[t]{2}{*}{ USU-1784 } & \multirow[t]{2}{*}{ Caldwell Creek } & SG-OSL & $178(400)$ & $1.27 \pm 0.14$ & $4.13 \pm 0.42$ & & $310 \pm 50$ \\
\hline & & FG-IRSL & $22(36)$ & $1.04 \pm 0.17$ & $6.83 \pm 0.54$ & $4.7 \pm 0.6$ & $210 \pm 50$ \\
\hline \multirow[t]{2}{*}{ USU-1786 } & \multirow[t]{2}{*}{ Platt } & SG-OSL & $346(500)$ & $3.24 \pm 0.11$ & $4.21 \pm 0.24$ & & $780 \pm 80$ \\
\hline & & FG-IRSL & $27(45)$ & $3.05 \pm 0.55$ & $7.15 \pm 0.52$ & $3.8 \pm 1.0$ & $670 \pm 140$ \\
\hline
\end{tabular}

${ }^{a}$ SG-OSL: Single-grain optically stimulated luminescence of quartz sand (63-250 $\left.\mu \mathrm{m}\right)$, or FG-IRSL: Fine-grain infrared stimulated luminescence of polymineral silt $(4-11 \mu \mathrm{m})$. All FG-IRSL ages are corrected for fading following Auclair et al. (2003) and the age correction model by Huntley and Lamothe (2001). Average fading rate $(3.9 \pm 0.6, n=48)$ applied to the Boulder Ridge samples.

${ }^{b}$ Number of grains/disks used in age calculation and number of grains/disks analyzed in parentheses.

${ }^{c}$ Equivalent dose $\left(D_{E}\right)$ calculated using an unlogged central age model (CAMUL, Galbraith and Roberts 2012). Error reported at two-sigma standard error.

${ }^{\mathrm{d}}$ See Ideker et al. (2017) for data and description of dose-rate calculation.

${ }^{\mathrm{e}}$ Datum for OSL and IRSL ages is AD 2010. Ages reported at two-sigma standard error.

${ }^{\mathrm{f}} \mathrm{D}_{\mathrm{E}}$ calculated using the mean. Error reported at two-sigma standard error.

Two samples were analyzed from Lodge CC and one sample from Lodge $\mathrm{S}$ at High Rise Village. The two Lodge CC samples returned SG-OSL age estimates of $530 \pm 90 \mathrm{yr}$ (USU$1782)$ and $520 \pm 70 \mathrm{yr}$ (USU-1783). Although the area around Lodge CC burned during a historic wildfire, as evidenced by charred standing remnant wood, the fire does not seem to have affected the luminescence signals of the buried sherds. Only one of two sherds from Lodge S (USU-1781) yielded enough material for dating, producing a SG-OSL age of $680 \pm 70 \mathrm{yr}$. Based on the absence of burned timbers, Lodge $S$ appears to have been beyond the margins of the wildfire that burned Lodge CC.

Two sherds were analyzed from the Caldwell Creek site and one from the Platt site. The one sherd large enough for analysis at the Caldwell Creek site (USU-1784) produced an age of 310 \pm 50 yr. The Platt site sherd (USU-1786) was dated to $780 \pm 80 \mathrm{yr}$. Although the Caldwell Creek site burned during the AD 2011 Norton
Point wildfire, the analyzed sherd came from an excavated context approximately $15 \mathrm{~cm}$ below the ground surface and displayed no evidence for recent thermal resetting. The Platt site sample also came from an excavated context, although the exact depth is unknown.

\section{Independent Chronological Comparisons.} The ceramic samples were selected from contexts that had radiocarbon age chronologies (Table 2), and the SG-OSL method provided independent age control for potentially problematic contexts. Moreover, as a comparative test, we applied polymineral FG-IRSL dating to each sherd. In our samples, the SG-OSL results show improved accuracy and precision over radiocarbon dating, and while FG-IRSL ages are within error of the SG-OSL results in all cases, SG-OSL ages are more precise (Figure 3), validating its use in constructing archaeological chronologies.

Three radiocarbon ages from a buried feature at Boulder Ridge returned highly variable 
Table 2. Radiocarbon Age Information.

\begin{tabular}{|c|c|c|c|c|c|c|c|c|}
\hline Site & Lab ID & Sample ID & Lodge & Context & $\delta^{13} \mathrm{C}$ & ${ }^{14} \mathrm{C}_{\text {age }}{ }^{\mathrm{a}}$ & $\begin{array}{c}2 \sigma \text { calibrated } \\
\text { age range }^{b}\end{array}$ & $\begin{array}{l}\text { Median age }^{\mathrm{c}} \\
\left(\mathrm{yr} \mathrm{BP}_{2010}\right)\end{array}$ \\
\hline \multirow[t]{3}{*}{ Boulder Ridge } & AA-98838 & 48PA2665-38 & I & Hearth/Charcoal & -23.2 & $570 \pm 30$ & $\begin{array}{l}527-566[0.395] \\
585-646[0.605]\end{array}$ & $650 \pm 60$ \\
\hline & AA-98839 & 48РA2665-39 & I & Hearth/Charcoal & -23.6 & $960 \pm 40$ & $\begin{array}{l}786-938[0.992] \\
946-952[0.008]\end{array}$ & $930 \pm 80$ \\
\hline & AA-98840 & 48РA2665-40 & I & Hearth/Charcoal & -22.7 & $980 \pm 30$ & $\begin{array}{l}796-875[0.515] \\
892-956[0.485]\end{array}$ & $950 \pm 80$ \\
\hline \multirow[t]{3}{*}{ High Rise Village } & Beta-245981 & FR5891 LODGE S & $\mathrm{S}$ & Hearth/Charcoal & - & $840 \pm 40$ & $\begin{array}{l}680-800[0.908] \\
814-826[0.017] \\
866-901[0.075]\end{array}$ & $850 \pm 110$ \\
\hline & Beta- $248565^{\mathrm{d}}$ & FR5891 LODGE CC & $\mathrm{CC}$ & Structural timber/Wood & - & $420 \pm 50$ & $\begin{array}{l}317-396[0.264] \\
423-535[0.736]\end{array}$ & $490 \pm 110$ \\
\hline & Beta-269156 ${ }^{\mathrm{d}}$ & FR5891 LODGE CC-2 & $\mathrm{CC}$ & Sherd residue & - & $130 \pm 40$ & $\begin{array}{l}7-47[0.162] \\
55-152[0.420] \\
171-280[0.419]\end{array}$ & $200 \pm 140$ \\
\hline$\overline{\text { Platt }}$ & UCIAMS-147405 & CSI-PS-30 burnt residue & - & Sherd residue & -110.9 & $945 \pm 25$ & $\begin{array}{l}796-888[0.754] \\
890-922[0.246]\end{array}$ & $920 \pm 60$ \\
\hline
\end{tabular}

${ }^{\mathrm{a}}$ Conventional radiocarbon age $( \pm 1 \sigma$ error) reported in radiocarbon years before $\mathrm{AD} 1950(\mathrm{BP})$.

${ }^{\mathrm{b}}$ Using IntCal13 calibration curve from Reimer et al. 2013; probability in brackets.

${ }^{\mathrm{c}}$ Calibrated ages rounded to the nearest decade and reported at two-sigma error in years before $\mathrm{AD} 2010\left(\mathrm{BP}_{2010}\right)$ by adding 60 years to calibrated age.

${ }^{\mathrm{d}}$ Samples originally reported in Morgan, Losey, and Adams 2012. 

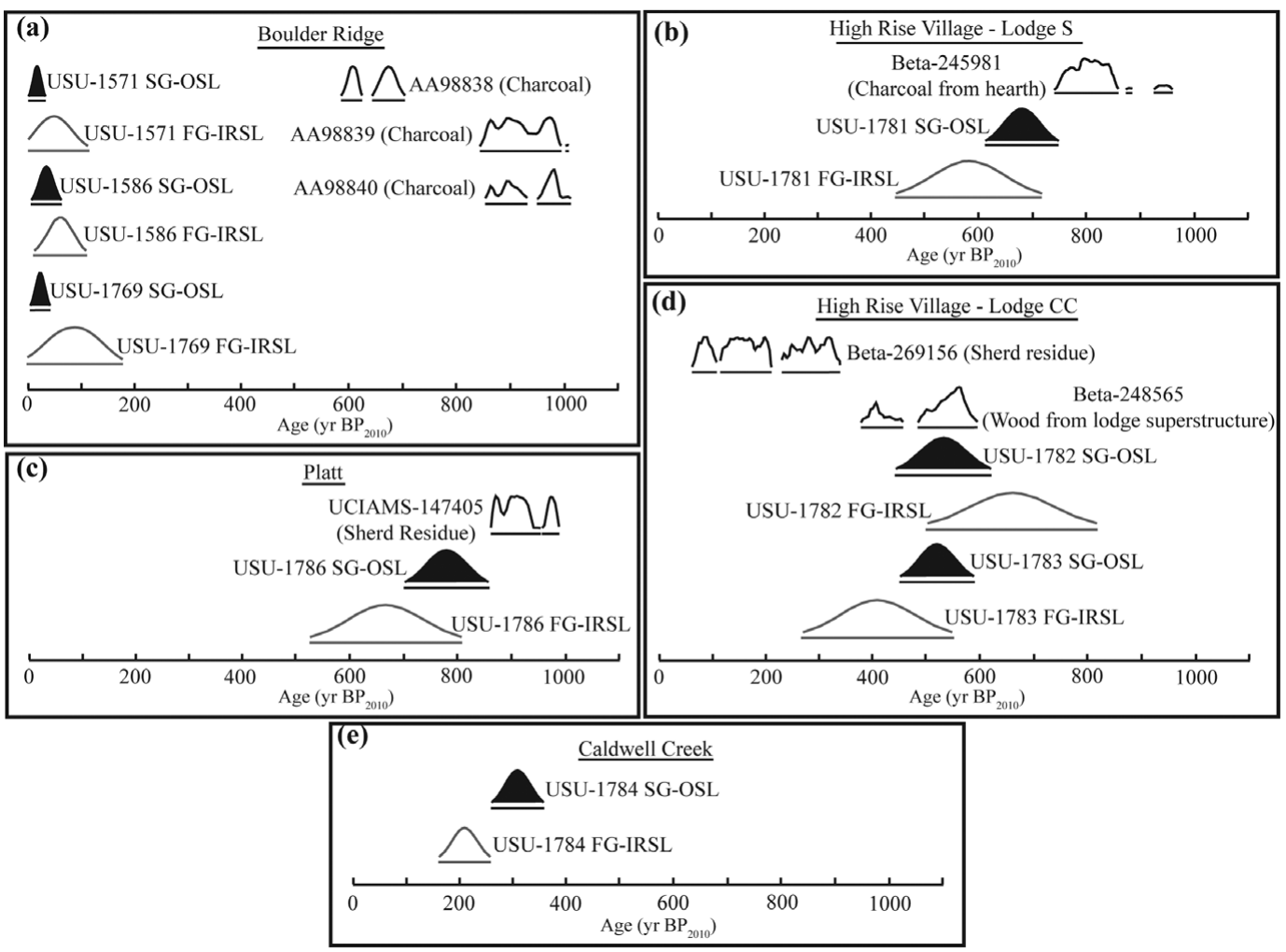

Figure 3. Age distributions of single-grain OSL, fine-grain IRSL, and radiocarbon ages for brownware samples from (a) Boulder Ridge, (b) High Rise Village Lodge S, (c) the Platt site, (d) High Rise Village Lodge CC, and (e) Caldwell Creek.

radiocarbon ages ranging from $650-950 \mathrm{cal}$ $\mathrm{BP}_{2010}$ (Figure 3, Table 1). These radiocarbon ages are from a hearth inside a house structure; the recovered sherds were from the surface adjacent to the structure, and the association between the structure and sherds is unclear, although the proximity suggests they are related. The three analyzed Boulder Ridge sherds returned nearzero SG-OSL age estimates, indicating recent signal resetting during the Boulder Basin II wildfire in AD 2003, which is supported by FG-IRSL ages of $50 \pm 70 \mathrm{yr}$ (USU-1571), 60 $\pm 50 \mathrm{yr}$ (USU-1586), and $80 \pm 90 \mathrm{yr}$ (USU1769). Unfortunately, these results do not help resolve the occupation age. A previous analysis of sherds presumably from the same vessel at Boulder Ridge produced luminescence results that range from 1500-2800 yr (Feathers 2014). These results predate known regional ceramic ages by as much as a few thousand years (Kornfeld at el. 2010). While we cannot account for the anomalously old results from the previous study, the quartz SG-OSL and polymineral FG-IRSL ages suggest our results record the most recent heating event of the quartz temper and fine-grain paste from the analyzed sherds.

Associated radiocarbon ages from Lodge CC at High Rise Village are $490 \pm 110$ cal $\mathrm{BP}_{2010}$ from the structural timber of the lodge and 200 \pm 140 cal $\mathrm{BP}_{2010}$ on residue from a ceramic sherd collected during excavation but not dated in this study. The two Lodge CC sherds included in this study returned FG-IRSL ages of $660 \pm$ $160 \mathrm{yr}$ (USU-1782) and $410 \pm 140 \mathrm{yr}$ (USU1783). The SG-OSL, polymineral FG-IRSL, and radiocarbon age on the structural timber are all within error of each other, suggesting that they all independently date the lodge occupation (Figure 3). The radiocarbon age on sherd residue is younger than the other age data, suggesting that the sherd residue in this case does not accurately date the occupation. Charcoal from a hearth 
in Lodge $\mathrm{S}$ returned a radiocarbon age of 850 $\pm 110 \mathrm{cal} \mathrm{BP}_{2010}$, which is significantly older than the SG-OSL age, suggesting a possible oldwood problem in this feature. The analyzed sherd returned an FG-IRSL age of $580 \pm 140 \mathrm{yr}$ (USU1781) from the ceramic paste, and although this is not a very precise age, it is within error of the SG-OSL age. Our results suggest that the SGOSL manufacturing age of the ceramic vessel from Lodge $\mathrm{S}$ most closely approximates the occupation age of that structure.

While no independent radiocarbon ages are available from the Caldwell Creek site, our FGIRSL age from the sampled sherd (USU-1784) provides independent validation of the SG-OSL age. The FG-IRSL age of $210 \pm 140 \mathrm{yr}$ is within error of the single-grain age of $310 \pm 50 \mathrm{yr}$ (Table 1).

Age control from the Platt site includes a radiocarbon date on organic residue from the vessel interior, which returned an age estimate of $920 \pm 60 \mathrm{cal} \mathrm{BP} 2010$. The two-sigma error of this age estimate adjoins the SG-OSL age of 780 $\pm 80 \mathrm{yr}$ from the same sherd (Figure 2). The Platt site sherd is the only sample in our study with the greatest difference between the SG-OSL and FGIRSL ages. Although within error, the younger FG-IRSL age of $670 \pm 140 \mathrm{yr}$ may be due to uncertainties in the fading measured during FGIRSL analysis.

Accuracy and Precision in the $S G$ OSL Method. Accuracy and precision are arguably the two most important variables in any geochronological method. Radiocarbon chronologies are particularly challenging given uncertainties in the agreement between measured and target ages, sometimes producing discrepancies on the order of centuries or millennia. Differences between measured and target ages in high-elevation settings like the MRM are amplified by the persistence of old wood that may be incorporated into archaeological features at high elevations. Furthermore, as most sites are discovered during post-wildfire surveys, building radiocarbon chronologies is made even more difficult by the abundance of recent charcoal at these sites. Another challenge to radiocarbon dating is variability in the radiocarbon calibration curve over the last 1,500 years (Reimer et al.
2013), which amplifies uncertainties in calibrated age distributions. These problems alone speak to the need for additional geochronological techniques that operate independently of the old wood and calibration problems inherent in radiocarbon dating.

We suggest that the relatively short use-life of hunter-gatherer pottery is encompassed within the error terms of an SG-OSL age, eliminating the need for extensive bridging arguments and reducing the uncertainty between the measured event (i.e., vessel manufacture) and target event (i.e., site occupation). Our results show that quartz grains in brownware sherd temper are reliable chronometers, as firing temperatures are expected to consistently reset quartz luminescence signals and will sensitize them, producing "bright" grains conducive for precise analysis. Moreover, consistently reset signals during vessel firing increase precision of the age distribution by reducing grain-to-grain age uncertainties and by producing smaller two-sigma standard error estimates (Figure 3). Two-sigma standard errors of samples not reset by wildfires in this study are well within errors of similar-aged calibrated radiocarbon ages, a process not required for OSL dating, which produces ages in calendar years. Additionally, the ability of SG-OSL to focus exclusively on the sand-sized quartz fraction rather than a polymineral silt fraction, as dated with FG-IRSL and TL methods, results in a more definitive age estimate. Our robust results validate the use of SG-OSL on ceramics and warrant further applications to archaeological studies.

\section{Rethinking Brownware Adoption and Technological Diffusion}

Our results provide the first direct dates on archaeological ceramics for the MRM that we know of and have important implications for the diffusion and adoption of ceramic technology from the adjacent Great Basin. In the following sections, we refer to OSL, IRSL, and TL age estimates on ceramics as a direct date of pottery manufacture age. We compare our results with a sample of directly dated brownwares from the SGB and EGB (Table 3) as a test of the hypothesis that brownware ceramics in the MRM 
Table 3. Direct (TL and OSL) Ages on Regional Brownware Ceramics.

\begin{tabular}{|c|c|c|c|c|c|}
\hline $\begin{array}{l}\text { Sample } \\
\text { Lab } \\
\text { Number }\end{array}$ & Site & Method & $\begin{array}{c}\text { OSL/ } \\
\text { TL Age } \\
(\text { yr BP } 2010)\end{array}$ & $\begin{array}{l}2 \sigma \text { Age } \\
\text { Range } \\
\left(\mathrm{BP}_{2010}\right)\end{array}$ & Reference \\
\hline USU-1571 & Boulder Ridge & OSL & $18 \pm 16$ & $34-2$ & Ideker et al. 2017 \\
\hline USU-1569 & Boulder Ridge & OSL & $23 \pm 19$ & $42-4$ & Ideker et al. 2017 \\
\hline USU-1786 & Boulder Ridge & OSL & $34 \pm 27$ & $61-7$ & Ideker et al. 2017 \\
\hline USU-1781 & HRV Lodge S & OSL & $680 \pm 70$ & $750-610$ & Ideker et al. 2017 \\
\hline USU-1782 & HRV Lodge CC & OSL & $530 \pm 90$ & $620-440$ & Ideker et al. 2017 \\
\hline USU-1783 & HRV Lodge CC & OSL & $520 \pm 70$ & $590-450$ & Ideker et al. 2017 \\
\hline USU-1785 & Caldwell Creek & OSL & $310 \pm 50$ & $360-260$ & Ideker et al. 2017 \\
\hline USU-1786 & Platt & OSL & $780 \pm 80$ & $860-700$ & Ideker et al. 2017 \\
\hline UWTL-91 & O’Malley Shelter & TL & $482 \pm 82$ & $564-400$ & Rhode 1994 \\
\hline UWTL-88 & Conaway Shelter & $\mathrm{TL}$ & $1172 \pm 210$ & $1382-962$ & Rhode 1994 \\
\hline UWTL-89 & Conaway Shelter & TL & $928 \pm 148$ & $1076-780$ & Rhode 1994 \\
\hline UWTL-64 & Yucca Mountain & $\mathrm{TL}$ & $913 \pm 200$ & $1114-714$ & Rhode 1994 \\
\hline UWTL-68 & Yucca Mountain & TL & $510 \pm 74$ & $584-436$ & Rhode 1994 \\
\hline UWTL-81 & Yucca Mountain & $\mathrm{TL}$ & $498 \pm 70$ & $568-428$ & Rhode 1994 \\
\hline UWTL-83 & Yucca Mountain & $\mathrm{TL}$ & $462 \pm 56$ & $518-406$ & Rhode 1994 \\
\hline UWTL-65 & Yucca Mountain & $\mathrm{TL}$ & $419 \pm 72$ & $491-347$ & Rhode 1994 \\
\hline UWTL-90 & Yucca Mountain & $\mathrm{TL}$ & $413 \pm 60$ & $474-353$ & Rhode 1994 \\
\hline UWTL-67 & Yucca Mountain & TL & $182 \pm 28$ & $210-154$ & Rhode 1994 \\
\hline UWTL-84 & Yucca Mountain & $\mathrm{TL}$ & $180 \pm 28$ & $208-152$ & Rhode 1994 \\
\hline UWTL-63 & Yucca Mountain & $\mathrm{TL}$ & $158 \pm 38$ & $196-220$ & Rhode 1994 \\
\hline UWTL-99 & Owens Valley & $\mathrm{TL}$ & $340 \pm 56$ & $396-284$ & Rhode 1994 \\
\hline UWTL-100 & Owens Valley & $\mathrm{TL}$ & $332 \pm 96$ & $430-234$ & Rhode 1994 \\
\hline UWTL-87 & Hogup Cave & TL & $167 \pm 20$ & $187-147$ & Rhode 1994 \\
\hline UWTL-128 & Nevada Test Site & $\mathrm{TL}$ & $232 \pm 42$ & $278-194$ & Feathers and Rhode 1998 \\
\hline UWTL-129 & Nevada Test Site & TL & $454 \pm 98$ & $556-360$ & Feathers and Rhode 1998 \\
\hline UWTL-130 & Nevada Test Site & $\mathrm{TL}$ & $544 \pm 158$ & $706-390$ & Feathers and Rhode 1998 \\
\hline UWTL-131 & Nevada Test Site & $\mathrm{TL}$ & $154 \pm 52$ & $210-106$ & Feathers and Rhode 1998 \\
\hline UWTL-132 & Nevada Test Site & $\mathrm{TL}$ & $356 \pm 170$ & $530-190$ & Feathers and Rhode 1998 \\
\hline UWTL-133 & Nevada Test Site & TL & $207 \pm 82$ & $293-129$ & Feathers and Rhode 1998 \\
\hline UWTL-134 & Nevada Test Site & TL & $518 \pm 110$ & $632-412$ & Feathers and Rhode 1998 \\
\hline UW1053 & 42WS3636 & $\mathrm{TL}$ & $556 \pm 98$ & $654-458$ & Feathers 2006 \\
\hline UW1054 & $42 \mathrm{WS} 1220$ & TL & $108 \pm 18$ & $126-90$ & Feathers 2006 \\
\hline UW1055 & $42 \mathrm{WS} 2350$ & $\mathrm{TL}$ & $386 \pm 82$ & $468-304$ & Feathers 2006 \\
\hline UW1056 & 26CK2954 & $\mathrm{TL}$ & $184 \pm 104$ & $288-80$ & Feathers 2006 \\
\hline UW1057 & 26CK2954 & TL & $255 \pm 84$ & $339-171$ & Feathers 2006 \\
\hline UW1058 & 26CK2954 & TL & $211 \pm 44$ & $255-167$ & Feathers 2006 \\
\hline UW1059 & 42WS3636 & TL & $199 \pm 36$ & $235-163$ & Feathers 2006 \\
\hline UW1060 & $42 \mathrm{WS} 1220$ & $\mathrm{TL}$ & $1323 \pm 312$ & $1635-1011$ & Feathers 2006 \\
\hline UW1061 & 26CK2954 & TL & $754 \pm 76$ & $830-678$ & Feathers 2006 \\
\hline UW803 & 42UT735 & $\mathrm{TL}$ & $363 \pm 50$ & $413-313$ & Reed 2005 \\
\hline UW804 & 42MD996 & TL & $297 \pm 40$ & $337-257$ & Reed 2005 \\
\hline UW805 & 42MD996 & TL & $388 \pm 134$ & $522-254$ & Reed 2005 \\
\hline UW806 & 42BE1354 & TL & $373 \pm 128$ & $501-245$ & Reed 2005 \\
\hline UW807 & 42BE1354 & TL & $409 \pm 112$ & $521-297$ & Reed 2005 \\
\hline UW808 & 42IN848 & $\mathrm{TL}$ & $464 \pm 150$ & $614-314$ & Reed 2005 \\
\hline UW809 & $42 \mathrm{IN} 848$ & TL & $563 \pm 114$ & $677-449$ & Reed 2005 \\
\hline UW810 & 42IN848 & $\mathrm{TL}$ & $352 \pm 136$ & $488-216$ & Reed 2005 \\
\hline UW811 & 42IN1213 & $\mathrm{TL}$ & $1302 \pm 256$ & $1814-790$ & Reed 2005 \\
\hline UW812 & 42WS316 & TL & $484 \pm 156$ & $640-328$ & Reed 2005 \\
\hline UW813 & 42WS1579 & $\mathrm{TL}$ & $318 \pm 108$ & $426-210$ & Reed 2005 \\
\hline UW814 & 42WS1579 & TL & $259 \pm 128$ & $387-131$ & Reed 2005 \\
\hline UW815 & $42 \mathrm{WS} 1583$ & $\mathrm{TL}$ & $315 \pm 126$ & $441-189$ & Reed 2005 \\
\hline UW816 & 42WS1754 & $\mathrm{TL}$ & $504 \pm 344$ & $848-160$ & Reed 2005 \\
\hline
\end{tabular}


Table 3. Continued.

\begin{tabular}{|c|c|c|c|c|c|}
\hline $\begin{array}{l}\text { Sample } \\
\text { Lab } \\
\text { Number }\end{array}$ & Site & Method & $\begin{array}{c}\text { OSL/ } \\
\text { TL Age } \\
\left(\mathrm{yr} \mathrm{BP}_{2010}\right)\end{array}$ & $\begin{array}{l}2 \sigma \text { Age } \\
\text { Range } \\
\left(\mathrm{BP}_{2010}\right)\end{array}$ & Reference \\
\hline UW817 & 42WS2465 & TL & $162 \pm 62$ & $224-100$ & Reed 2005 \\
\hline UW818 & 42WS2489 & TL & $291 \pm 88$ & $379-203$ & Reed 2005 \\
\hline UW883 & 42UT698 & TL & $406 \pm 126$ & $532-280$ & Reed 2005 \\
\hline UW884 & 42UT698 & TL & $424 \pm 90$ & 514-334 & Reed 2005 \\
\hline UW885 & 42UT698 & $\mathrm{TL}$ & $241 \pm 38$ & 279-203 & Reed 2005 \\
\hline UW886 & 42UT698 & TL & $199 \pm 56$ & $255-143$ & Reed 2005 \\
\hline UW887 & 42WS1585 & $\mathrm{TL}$ & $716 \pm 106$ & $822-610$ & Reed 2005 \\
\hline UW888 & 42WS2434 & TL & $669 \pm 120$ & $789-549$ & Reed 2005 \\
\hline UW889 & 42WS2453 & TL & $284 \pm 76$ & $360-208$ & Reed 2005 \\
\hline UW902 & 42MD974 & $\mathrm{TL}$ & $729 \pm 190$ & $919-539$ & Reed 2005 \\
\hline UW903 & 42MD974 & TL & $831 \pm 225$ & $1281-381$ & Reed 2005 \\
\hline UW904 & 42MD974 & TL & $1149 \pm 230$ & 1379-919 & Reed 2005 \\
\hline UW905 & 42MD974 & $\mathrm{TL}$ & $320 \pm 220$ & $540-100$ & Reed 2005 \\
\hline UW906 & 42MD974 & TL & $307 \pm 188$ & $495-119$ & Reed 2005 \\
\hline UW907 & 42BE743 & $\mathrm{TL}$ & $1708 \pm 228$ & $1936-1480$ & Reed 2005 \\
\hline UW908 & 42BE743 & $\mathrm{TL}$ & $1376 \pm 144$ & $1520-1232$ & Reed 2005 \\
\hline UW909 & 42BE743 & $\mathrm{TL}$ & $1475 \pm 192$ & $1667-1283$ & Reed 2005 \\
\hline UW910 & 42BE743 & TL & $729 \pm 212$ & $941-517$ & Reed 2005 \\
\hline UW911 & $42 \mathrm{IN} 218$ & $\mathrm{TL}$ & $756 \pm 216$ & $972-540$ & Reed 2005 \\
\hline UW912 & $42 \mathrm{IN} 218$ & TL & $309 \pm 98$ & $407-211$ & Reed 2005 \\
\hline UW913 & 42WS1459 & TL & $637 \pm 116$ & $753-521$ & Reed 2005 \\
\hline UW914 & 42WS1459 & $\mathrm{TL}$ & $185 \pm 50$ & $235-135$ & Reed 2005 \\
\hline UW915 & 42WS1459 & $\mathrm{TL}$ & $341 \pm 64$ & $405-277$ & Reed 2005 \\
\hline UW916 & 42WS1459 & $\mathrm{TL}$ & $366 \pm 50$ & $416-316$ & Reed 2005 \\
\hline UW917 & 42WS1459 & TL & $281 \pm 74$ & $355-207$ & Reed 2005 \\
\hline UW946 & 42BE751 & TL & $710 \pm 228$ & $939-482$ & Reed 2005 \\
\hline UW947 & 42BE751 & TL & $626 \pm 506$ & $1132-120$ & Reed 2005 \\
\hline UW948 & 42BE751 & TL & $1072 \pm 220$ & $1292-852$ & Reed 2005 \\
\hline UW950 & 42BE751 & $\mathrm{TL}$ & $712 \pm 288$ & $1000-424$ & Reed 2005 \\
\hline UW951 & 42BE751 & $\mathrm{TL}$ & $225 \pm 82$ & $307-143$ & Reed 2005 \\
\hline UW952 & 42BE751 & $\mathrm{TL}$ & $335 \pm 80$ & $415-255$ & Reed 2005 \\
\hline UW953 & 42WS1460 & TL & $263 \pm 340$ & $603-0$ & Reed 2005 \\
\hline UW954 & 42WS1460 & TL & $156 \pm 22$ & $178-134$ & Reed 2005 \\
\hline UW955 & 42WS1460 & $\mathrm{TL}$ & $632 \pm 114$ & $746-518$ & Reed 2005 \\
\hline UW956 & 42WS1460 & $\mathrm{TL}$ & $338 \pm 146$ & 484-192 & Reed 2005 \\
\hline UW957 & 42WS1460 & $\mathrm{TL}$ & $297 \pm 31$ & $359-235$ & Reed 2005 \\
\hline UW958 & 42WS1460 & $\mathrm{TL}$ & $172 \pm 58$ & $230-114$ & Reed 2005 \\
\hline UW959 & 42WS1460 & $\mathrm{TL}$ & $204 \pm 138$ & $342-66$ & Reed 2005 \\
\hline UW960 & 42WS1460 & TL & $253 \pm 48$ & $301-205$ & Reed 2005 \\
\hline UW961 & 42WS1460 & TL & $311 \pm 176$ & $487-135$ & Reed 2005 \\
\hline UW962 & 42WS1460 & TL & $148 \pm 38$ & $186-110$ & Reed 2005 \\
\hline UW963 & 42WS1460 & TL & $186 \pm 26$ & $212-160$ & Reed 2005 \\
\hline UW964 & 42WS1460 & TL & $426 \pm 46$ & $472-380$ & Reed 2005 \\
\hline UW965 & 42WS1460 & $\mathrm{TL}$ & $173 \pm 32$ & $205-141$ & Reed 2005 \\
\hline UW966 & 42WS1460 & TL & $148 \pm 30$ & $178-118$ & Reed 2005 \\
\hline UW967 & 42WS1460 & TL & $174 \pm 148$ & $322-26$ & Reed 2005 \\
\hline UW968 & 42WS1579 & TL & $268 \pm 56$ & $324-212$ & Reed 2005 \\
\hline UW969 & 42WS1579 & $\mathrm{TL}$ & $424 \pm 116$ & $540-308$ & Reed 2005 \\
\hline UW970 & 42WS1579 & TL & $423 \pm 54$ & $477-369$ & Reed 2005 \\
\hline UW971 & 42WS1579 & $\mathrm{TL}$ & $665 \pm 258$ & $923-407$ & Reed 2005 \\
\hline UW1004 & 42WS2434 & $\mathrm{TL}$ & $1000 \pm 150$ & $1150-850$ & Reed 2005 \\
\hline UW1005 & 42WS2434 & TL & $831 \pm 136$ & $967-695$ & Reed 2005 \\
\hline UW1023 & 42WS2434 & TL & $1014 \pm 114$ & $1128-900$ & Reed 2005 \\
\hline
\end{tabular}


Table 3. Continued.

\begin{tabular}{|c|c|c|c|c|c|}
\hline $\begin{array}{l}\text { Sample } \\
\text { Lab } \\
\text { Number }\end{array}$ & Site & Method & $\begin{array}{c}\text { OSL/ } \\
\text { TL Age } \\
\left(\mathrm{yr} \mathrm{BP}_{2010}\right)\end{array}$ & $\begin{array}{c}2 \sigma \text { Age } \\
\text { Range } \\
\left(\mathrm{BP}_{2010}\right)\end{array}$ & Reference \\
\hline UW1024 & 42WS2434 & $\mathrm{TL}$ & $802 \pm 172$ & $974-630$ & Reed 2005 \\
\hline UW1025 & 42WS2434 & $\mathrm{TL}$ & $24 \pm 22$ & $46-2$ & Reed 2005 \\
\hline UW1026 & $42 \mathrm{WS} 2434$ & $\mathrm{TL}$ & $200 \pm 324$ & $524-0$ & Reed 2005 \\
\hline UW1027 & $42 \mathrm{WS} 2434$ & $\mathrm{TL}$ & $366 \pm 680$ & $1046-0$ & Reed 2005 \\
\hline UW1028 & 42WS2434 & TL & $503 \pm 102$ & $605-401$ & Reed 2005 \\
\hline UW949 & 42BE751 & TL & $658 \pm 98$ & $756-560$ & Reed 2005 \\
\hline
\end{tabular}

date only to the last 500 years and reflect a recent Numic migration from a Great Basin homeland. Rhode (1994) was among the first to directly date Great Basin brownwares to address adoption of ceramic technology from neighboring Formative Pueblo and Fremont societies in the SGB and the subsequent northern spread. Reed (2005) directly dated 73 ceramic artifacts from the SGB and EGB. Reed's goals included determining the age of Shinarump Brownware and Promontory Grayware in southern and northern Utah, respectively, determining the age range of brownwares across his study area, and to evaluate old wood problems in archaeological chronologies by comparing radiocarbon and luminescence ages from associated sites. These studies provide 102 luminescence ages on Great Basin pottery; all reported ages are TL results analyzed at the University of Washington luminescence laboratory. All ages are standardized to the year AD 2010 to account for minor differences in when samples were analyzed. The ages are reported in one standard error terms, which we doubled to produce two standard error estimates.

To compare the relative ages of pottery across the interior of western North America, we divided the region into three general physiographic zones (Figure 1). The SGB encompasses the Mohave Desert region, ranging from Owens Valley and Death Valley on the west to the Las Vegas Valley and Beaver Dam Wash (i.e., Saint George, Utah) on the east. The EGB includes all of western Utah north of Saint George to the Great Salt Lake Desert and the western margin of the Colorado Plateau and the Uinta Basin. The MRM here includes the Wyoming Basin and the mountain ranges of western Wyoming. No directly dated brownwares are known from Idaho or Montana.
Brownwares are consistently the oldest in the SGB, appearing in the archaeological record approximately 1,200 years ago and persisting into the Historic era (Figure 4). After several centuries of experimentation in the SGB, brownwares become more regular in the archaeological record and simultaneously make their first appearance in the EGB and MRM. Although the current sample of directly dated brownwares in the EGB $(n=12)$ and MRM $(n=5)$ is small, the sample distributions are not significantly different from the SGB sample (Figure 5; $F=0.927 ; d f=2$, $p<0.400$ ). The oldest directly dated brownware in the EGB comes from 42BE751 (Reed 2005), while the oldest MRM sample is from the Platt site. Importantly, Reed (2005:527) identified the 42BE751 sample as an unidentified brownware, and all other sampled ceramics from that site are Fremont variants. Regardless, the Platt site brownware sample is reliably and independently dated with SG-OSL, FG-IRSL, and radiocarbon on organic residue (Figure 2). Not only is this the oldest known brownware pottery in the MRM, but it is evidence that by the time pottery became common among the ancestral Numa of the SGB it was also being used by Numa as far north as the greater Yellowstone area.

A key element in the regional adoption of ceramic technology is proximity of forager populations to sedentary and semi-sedentary Formative societies (Upham 1994). In the SGB, brownwares emerged among foraging neighbors of the Virgin Branch Anasazi settlements, while in the EGB and MRM, interactions between foragers and semi-sedentary farmers occurred on the margins of the Fremont sphere. Fremont pottery and brownwares commonly co-occur in western Utah rockshelters (Reed 2005; Rhode 

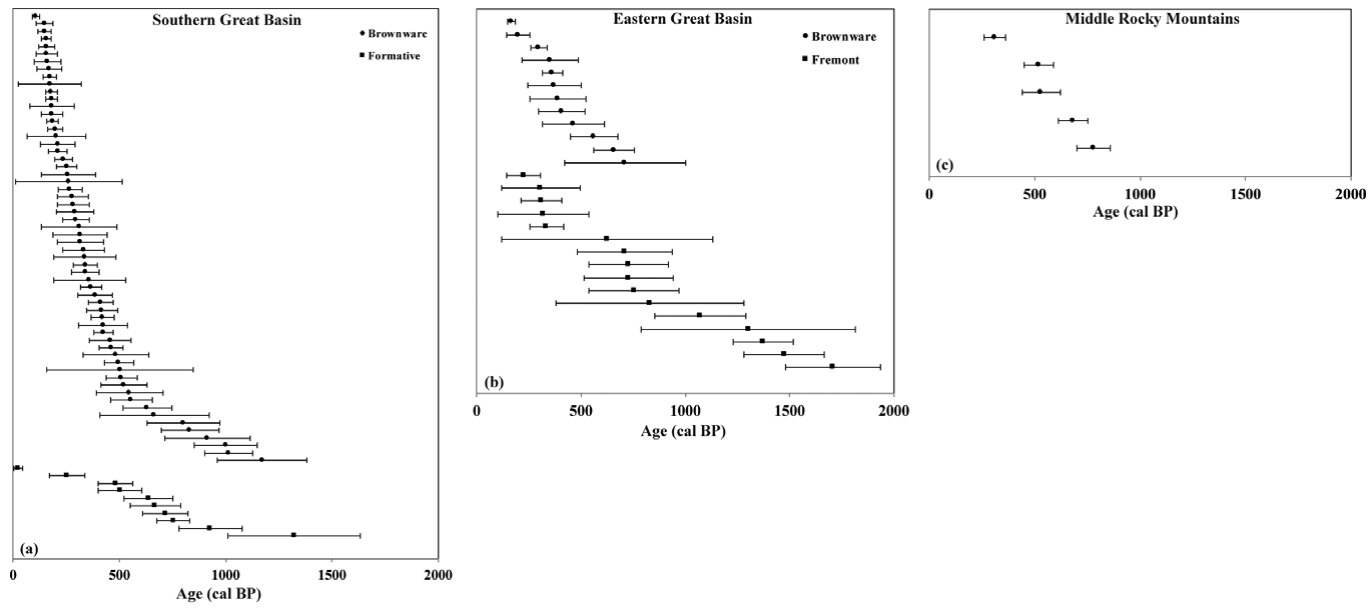

Figure 4. Age distributions of directly dated brownware and Formative pottery from (a) the southern Great Basin, (b) eastern Great Basin, and (c) Middle Rocky Mountains. Bars represent the two-sigma standard error.

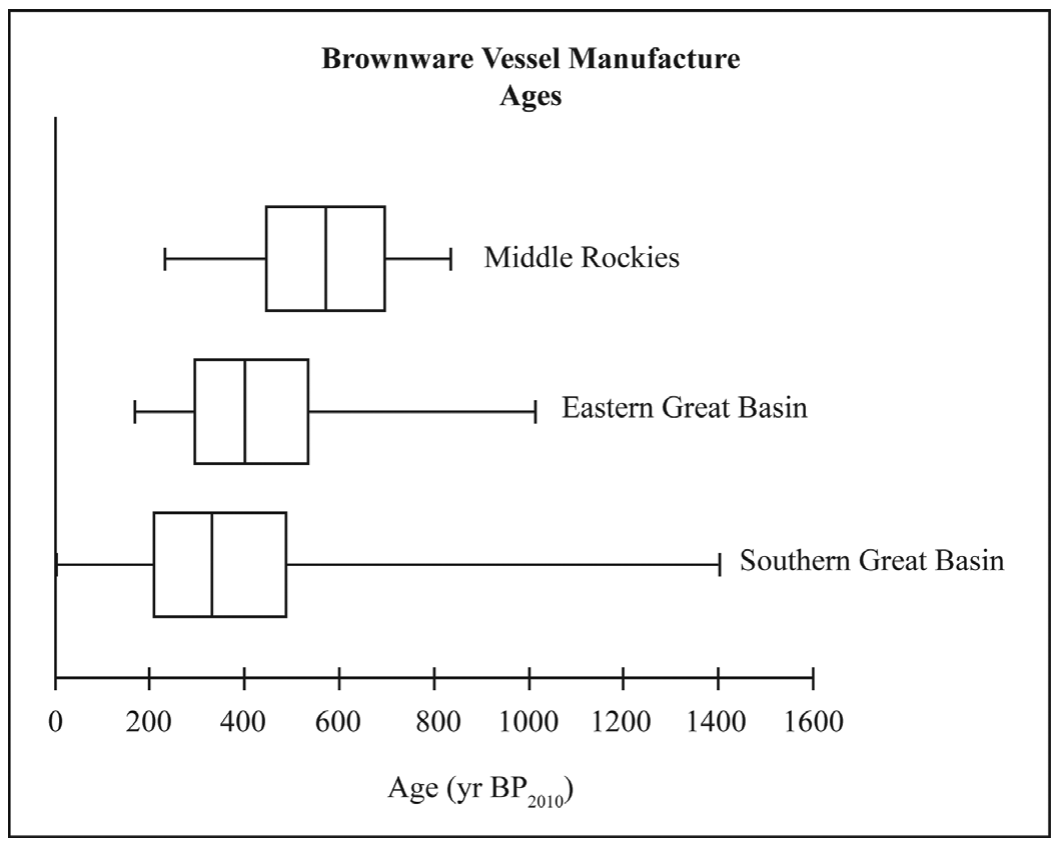

Figure 5. Box-and-whisker plot comparing the mean ages of brownwares from the three study areas.

1994), while Fremont pottery occurs at many sites in the Wyoming Basin (Smith 1992). Associated radiocarbon ages place the development of Fremont ceramics between AD 400-600 in the Uinta Basin and Wasatch Front sites (Madsen 1986) and in the Wyoming Basin (Smith 1992). Direct dates on Formative pottery from Reed's (2005) study demonstrate a significant difference in the mean age of the Formative and brownware samples $(t=-4.766 ; d f=103$; $p<0.001$ ), although there is considerable overlap with brownwares in the SGB and EGB (Figure 5). While Reed (2005:534) dismissed some Fremont samples on the extremes of both distributions as erroneous, the significant overlap suggests that knowledge of pottery production in Formative societies is critical in adoption of that technology among foragers (Upham 1994). 
Chronological issues aside, as Bright et al. (2002) suggest, foragers are likely to adopt ceramic technology under a selective context favoring increased efficiency. In the SGB, adoption of ceramic technology occurred alongside intensification of a small-seed economy and privatization of resources (Eerkens 2004). A focus on tuber procurement and intensification of bighorn sheep hunting during the last approximately 1,000 years (Frison et al. 1990) may have resulted in the adoption of similar stone and ceramic cooking technologies in the MRM.

\section{Conclusion}

Luminescence analysis has long been a preferred technique for archaeological chronology building, and improved technologies continually provide better control for ceramic manufacturing ages. By applying the SG-OSL method to the very fine to fine sand $(250-63 \mu \mathrm{m})$ fraction of quartz temper in brownware pottery, we show that ceramics are a reliable chronometer for the Late Prehistoric archaeological record, one that bypasses the old wood and calibration problems. Furthermore, SG-OSL yields greater precision in dating compared with the FG-IRSL technique. The main limitation of using SG-OSL lies in the abundance and mineralogy of sand temper, which is not present in all ceramic traditions.

Our study provides the first direct dates on brownwares in the MRM and shows that brownwares appeared in the regional archaeological record nearly 800 years ago. For decades, archaeologists have proposed that ceramics, as a marker of a supposed Numic expansion, should appear progressively younger with distance north from an SGB origin (Pippin 1986; Tuohy 1973; Wright 1978). While comparisons with directly dated brownwares from the SGB show that experimentation began there approximately 400 years earlier, brownwares appear in the EGB and MRM at nearly the same time. This coincides with Eerkens and Lipo's (2014) period of "mainstream" use in the SGB. The regional brownware chronology does not necessarily speak to a distinct population movement and replacement, as some have proposed for the historic distribution of Numic hunter-gatherers across the interior of western North America (Bettinger and Baumhoff
1982; Butler 1986; Janetski 1991; Wright 1978), although a rapid and archaeologically undetectable migration cannot be dismissed. Instead, the adoption of a relatively uniform brownware ceramic tradition may reflect technological diffusion across a stable regional population with deep, ancestral Numic roots (Francis and Loendorf 2002; Holmer 1994). Regardless, although the sample of directly dated brownwares in the MRM is small, the results firmly refute Wright's (1978) proposition that this technology dates to less than 500 years.

Perhaps more important than the timing is that the adoption of brownwares in the interior of western North America occurred on the periphery of Formative societies, particularly Virgin Branch Anasazi in the SGB and Fremont in the EGB and MRM (Upham 1994). Knowledge of ceramic technology on the margins of semisedentary and sedentary horticultural societies where individual behavioral strategies cycled on a continuum between full-time farming and fulltime foraging increased transmission of information across porous social boundaries (Madsen and Simms 1998; Upham 1994). Within this context, the adoption of ceramics is best understood as a time management solution to resource intensification (Bright et al. 2002). In the SGB, that process involved intensification and privatization of small seeds, while in the MRM, intensification (but perhaps not privatization) may have focused on tubers and bighorn sheep. These issues will remain central to understanding variability in human behavior and social history in the MRM as archaeological research continues.

Acknowledgments. Support for this research was provided by the Brigham Young University Charles Redd Foundation, University of Wyoming Frison Institute, and the Shoshone National Forest. Funding for Boulder Ridge radiocarbon analysis and ceramic luminescence analysis at the University of Washington came from National Science Foundation award \#714926 to principal investigator Laura Scheiber (Indiana University). Laura Scheiber also provided the Caldwell Creek samples for analysis. Bryon Schroeder coordinated analysis of High Rise Village sherds and provided important information about the archaeological context of artifacts from the site. Michelle Summa Nelson provided critical assistance in the single-grain OSL analysis at Utah State University. Heidi Roberts gave useful insight into data sources. Chantel Saban provided the Spanish translation of the abstract. 
Data Availability Statement. Luminescence samples prepared for this study and data for individual sample runs are archived at the Utah State University Luminescence Laboratory in Logan, Utah. Artifact collections from Boulder Ridge and High Rise Village are curated at the University of Wyoming Archaeological Repository. Materials from Caldwell Creek and the Platt site are currently curated at Indiana University and Utah State University, respectively.

\section{References Cited}

Adams, Richard

2010 Archaeology with Altitude: Late Prehistoric Settlement and Subsistence in the Northern Wind River Range, Wyoming. Unpublished PhD dissertation, Department of Anthropology, University of Wyoming, Laramie.

Aitken, Martin J.

1985 Thermoluminescence Dating. Academic Press, London.

1997 Luminescence Dating. In Chronometric Dating in Archaeology, edited by R. E. Taylor and Martin J. Aitken, pp. 183-216. Plenum Press, New York.

Auclair, M., M. Lamothe, and S. Huot

2003 Measurement of Anomalous Fading for Feldspar IRSL Using SAR. Radiation Measurements 37:487492.

Banerjee, Diptonil, Andrew S. Murray, Lars Botter Jensen, and Andreas Lang

2001 Equivalent Dose Estimation Using a Single Aliquot of Polymineral Fine Grains. Radiation Measurements 33:73-94.

Bettinger, Robert L.

1991 Aboriginal Occupation at High Altitude: Alpine Villages in the White Mountains of Eastern California. American Anthropologist 93:656-679.

Bettinger, Robert L., and Martin A. Baumhoff

1982 The Numic Spread: Great Basin Cultures in Competition. American Antiquity 47:484-503.

Bright, Jason, Andrew Ugan, and Lori Hunsaker

2002 The Effects of Handling Time on Subsistence Technology. World Archaeology 34:164-181.

Butler, B. Robert

1986 The Pottery of Eastern Idaho. In Pottery of the Great Basin and Adjacent Areas, edited by Suzanne Griset, pp. 37-57. University of Utah Anthropological Papers No. 111, Salt Lake City.

Coale, George L.

1963 A Study of Shoshonean Pottery. Tebiwa 6:1-11.

Dean, Patricia A.

1992 Prehistoric Pottery in the Northeastern Great Basin: Problems in the Classification and Archaeological Interpretation of Undecorated Fremont and Shoshone Wares. Unpublished PhD dissertation, Department of Anthropology, University of Oregon, Eugene.

Duller, Geoffrey A. T.

2008 Single-Grain Optical Dating of Quaternary Sediments: Why Aliquot Size Matters in Luminescence Dating. Boreas 37:589-612.

Eakin, Daniel H.

2005 Evidence for Shoshonean Mountain Sheep Trapping and Early Historic Occupation in the Absaroka Mountains of Northwest Wyoming. In University of Wyoming National Park Service Research Center 29th Annual
Report, edited by Henry J. Harlow and Maryanne Harlow, pp. 74-86. University of Wyoming, Laramie.

Eerkens, Jelmer W.

2003 Towards a Chronology of Brownware Pottery in the Western Great Basin: A Case Study from the Owens Valley. North American Archaeologist 24:1-27.

2004 Privatization, Small-Seed Intensification, and the Origins of Pottery in the Western Great Basin. American Antiquity 69:653-670.

2005 GC-MS Analysis and Fatty Acid Ratios of Archaeological Potsherds from the Western Great Basin of North America. Archaeometry 47:83-102.

Eerkens, Jelmer W., and Carl P. Lipo

2011 Luminescence Dating of Pottery from Owens Valley and Death Valley. Pacific Coast Archaeological Society Quarterly 47:101-114.

2014 A Tale of Two Technologies: Prehistoric Diffusion of Pottery Innovations among Hunter-Gatherers. Journal of Anthropological Archaeology 35:23-31.

Eerkens, Jelmer W., Hector Neff, and Michael D. Glascock

2002 Ceramic Production among Small-Scale and Mobile Hunters and Gatherers: A Case Study from the Southwestern Great Basin. Journal of Anthropological Archaeology 21:200-229.

Feathers, James K.

2003 Use of Luminescence Dating in Archaeology. Measurement Science and Technology 14: 1493-1509.

2006 Appendix D: Luminescence Dating of Pottery from Utah and Nevada. In The Coral Canyon II Project in the St. George Basin, Southwestern Utah, edited by Heidi Roberts and Suzanne Eskenazi, pp. 280-287. Archaeological Report No. 02-09, HRA Inc. Las Vegas, Nevada.

2008 Absolute Dating in the Mississippi Delta. In Time's River: Archaeological Syntheses from the Lower Mississippi River Valley, edited by Janet Rafferty and Evan Peacock, pp. 168-180. University of Alabama Press, Tuscaloosa.

2009 Problems of Ceramic Chronology in the Southeast: Does Shell-Tempered Pottery Appear Earlier than We Think? American Antiquity 74:113-142.

2014 Luminescence Analysis of Pottery from Northwestern Wyoming. Unpublished manuscript on file, University of Washington Luminescence Laboratory, Seattle, Washington.

Feathers, James K., and David Rhode

1998 Luminescence Dating of Protohistoric Pottery from the Great Basin. Geoarchaeology: An International Journal 13:287-308.

Finley, Judson B., and Maureen P. Boyle

2014 The Frequency and Typology of Ceramic Sites in Western Wyoming. Plains Anthropologist 59:3857.

Finley, Judson B., Maureen P. Boyle, and David C. Harvey

2015 Obsidian Conveyance in the Mountain World of the Numa. In Papers in Honor of James Benedict, Plains Anthropologist Memoir 43, edited by Kenneth P. Cannon, Judson B. Finley, and Molly B. Cannon. Plains Anthropologist 60:87-103.

Finley, Judson B., and Laura L. Scheiber

2010 A Pilot Provenance Study of Intermountain Ware Ceramics in Western Wyoming. Poster presented at the 75th Annual Meeting of the Society for American Archaeology, St. Louis, Missouri.

Forget Brisson, Laurence, Michel Lamothe, Sebastien Huot, Francois Hardy, and Claude Chapdelaine 
2015 Optical Dating of St. Lawrence Iroquoian Ceramics from the Mailhot-Curran Site, Southern Québec. Quaternary Geochronology 30:392-397.

Francis, Julie E., and Lawrence L. Loendorf

2002 Ancient Visions: Petroglyphs and Pictographs of the Wind River and Bighorn Country, Wyoming and Montana. University of Utah Press, Salt Lake City.

Frison, George C.

1971 Shoshonean Antelope Procurement in the Upper Green River Basin, Wyoming. Plains Anthropologist 16:258-284.

Frison, George C., Charles A. Reher, and Danny N. Walker

1990 Prehistoric Mountain Sheep Hunting in the Central Rocky Mountains of North America. In Hunters of the Recent Past, edited by Leslie B. Davis and Brian O.K. Reeves, pp. 208-240. Unwin-Hyman, Boston.

Galbraith, Rex, and Richard Roberts

2012 Statistical Aspects of Equivalent Dose and Error Calculations and Display in OSL Dating: An Overview and Some Recommendations. Quaternary Geochronology 11:1-27.

Haspel, Howard

1984 A Study of Shoshonean Ceramics of Wyoming: The Bugas-Holding Ceramic Assemblage. The Wyoming Archaeologist 27:25-40.

Hoebel, E. Adamson

1938 Bands and Distribution of the Eastern Shoshone. American Anthropologist 40:410-413.

Holmer, Richard N.

1994 In Search of the Ancestral Northern Shoshone. In Across the West: Human Population Movement and Expansion of the Numa, edited by David B. Madsen and David Rhode, pp. 179-187. University of Utah Press, Salt Lake City.

Huntley, David, Dorothy Godfrey-Smith, and Michael Thewalt

1985 Optical Dating of Sediments. Nature 313:105-107.

Huntley, David, and Michel Lamothe

2001 Ubiquity of Anomalous Fading in K-Feldspars and the Measurement and Correction for it in Optical Dating. Canadian Journal of Earth Science 38:1093-1106.

Ideker, Carlie J.

2016 A Light in the Dark: Luminescence Dating Intermountain Ware Ceramics from Four Archaeological Sites in Northwestern Wyoming. Unpublished Master's thesis, Department of Anthropology, Utah State University, Logan, Utah.

Ideker, Carlie J., Judson B. Finley, Tammy M. Rittenour, and Michelle S. Nelson

2017 Single-Grain Optically Stimulated Luminescence Dating of Quartz Temper from Prehistoric Ceramics, Northwestern Wyoming, USA. Quaternary Geochronology, in press.

Janetski, Joel C.

1991 Ethnicity and Post-Formative Ceramics in the Eastern Great Basin. In Hunter-Gatherer Pottery of the Far West, edited by JoAnn Mack, pp. 54-66. Nevada State Museum Anthropological Papers 23, Carson City.

Kornfeld, Marcel, George C. Frison, and Mary Lou Larson

2010 Prehistoric Hunter-Gatherers of the High Plains and Rockies, 3rd ed. Left Coast Press, Walnut Creek, California.

Lipo, Carl P., James K. Feathers, and Robert C. Dunnell

2005 Temporal Data Requirements, Luminescence Dates, and the Resolution of Late Prehistoric Deposits in the
Central Mississippi River Valley. American Antiquity 70:527-544.

Murray, Andrew, and Ann Wintle

2000 Luminescence Dating of Quartz Using an Improved Single-Aliquot Regenerative-Dose Protocol. Radiation Measurements 32:57-73.

Madsen, David B.

1986 Prehistoric Ceramics. In Great Basin, edited by Warren L. d'Azevedo, pp. 206-214. Handbook of North American Indians, Vol. 11, William C. Sturtevant, general editor, Smithsonian Institution, Washington, DC.

Madsen, David B., and Steven R. Simms

1998 The Fremont Complex: A Behavioral Perspective. Journal of World Prehistory 12:255-336.

Morgan, Christopher, Jacob Fisher, and Monique M. Pomerleau

2012 High-Altitude Intensification and Settlement in Utah's Pahvant Range. Journal of California and Great Basin Anthropology 32:27-45.

Morgan, Christopher, Ashley Losey, and Richard A. Adams

2012 High-Altitude Hunter-Gatherer Residential Occupations in Wyoming's Wind River Range. North American Archaeologist 33:35-79.

Murray, Andrew S., and Ann G. Wintle

2000 Luminescence Dating of Quartz Using an Improved Single-Aliquot Regenerative Dose Protocol. Radiation Measurements 32:57-73.

Nelson, Michelle S., Harrison J. Gray, Jack A. Johnson, Tammy M. Rittenour, James K. Feathers, and Shannon A. Mahan

2015 User Guide for Luminescence Sampling in Archaeological and Geological Contexts. Advances in Archaeological Practice 3:166-177.

Pippin, Lonnie C.

1986 Intermountain Brown Wares: An Assessment. In Pottery of the Great Basin and Adjacent Areas, edited by Suzanne Griset, pp. 9-21. University of Utah Anthropological Papers No. 111, Salt Lake City.

Platt, Jim, and Susan Hughes

1986 Preliminary Investigations at the Platt Site (48PA848), Park County, Wyoming. Wyoming Archaeologist 29:145-150.

Prescott, J. R., and J. T. Hutton

1995 Environmental Dose Rates and Radioactive Disequilibrium from Some Australian Luminescence Dating Sites. Quaternary Science Reviews 14:439-448.

Reed, Alan D.

2005 Thermoluminescence Dating of Ceramics. In Kern River 2003 Expansion Project, Utah-Volume IV: Prehistoric Synthesis-Examination of Data by Archaeological Unit, edited by Alan D. Reed, Matthew Seddon, and Heather Stettler, pp. 525-538. Alpine Archaeological Consultants, Montrose, Colorado, and SWCA, Inc., Salt Lake City, Utah.

Reimer, Paula J., Edouard Bard, Alex Bayliss, J. Warren Beck, Paul G. Blackwell, Christopher Bronk Ramsey, Caitlin E. Buck, Hai Cheng, R. Lawrence Edwards, Michael Friedrich, Pieter M. Grootes, Thomas P. Guilderson, Haflidi Haflidason, Irka Hajdas, Christine Hatté, Timothy J. Heaton, Dirk L. Hoffmann, Alan G. Hogg, Konrad A. Hughen, K. Felix Kaiser, Bernd Kromer, Sturt W. Manning, Mu Niu, Ron W. Reimer, David A. Richards, E. Marian Scott, John R. Southon, Richard A. Staff, Christian S. M. Turney, and Johannes van der Plicht 
2013 IntCal13 and Marine13 Radiocarbon Age Calibration Curves 0-50,000 Years cal B.P. Radiocarbon 55:1869-1887.

Rhode, David

1994 Direct Dating of Brown Ware Ceramics using Thermoluminescence and its Relation to the Numic Spread. In Across the West: Human Population Movement and Expansion of the Numa, edited by David B. Madsen and David Rhode, pp. 124-132. University of Utah Press, Salt Lake City.

Rittenour, Tammy M., Larry L. Coats, and Duncan Metcalfe 2015 Investigation of Late and Post-Fremont Alluvial Stratigraphy of Range Creek, East-Central Utah: Use of OSL when Radiocarbon Fails. Quaternary International 362:63-76.

Rittenour, Tammy M., Ronald J. Goble, and Michael D. Blum 2005 Development of an OSL Chronology for Late Pleistocene Channel Belts in the Lower Mississippi Valley, USA. Quaternary Science Reviews 24:25392554.

Scheiber, Laura L., Amanda Burtt, Amanda Riley, and Elizabeth Woodruff

2014 Continued Investigations at a High-Altitude Mountain Shoshone Campsite in Caldwell Basin, Fremont County, Wyoming. Poster presented at the 72nd Annual Plains Anthropological Conference, Fayetteville, Arkansas.

Scheiber, Laura L., and Judson B. Finley

2010 Mountain Shoshone Technological Transition across the Great Divide. In Across the Great Divide: Continuity and Change in Native North American Societies 1400-1900, edited by Laura L. Scheiber and Mark D. Mitchell, pp. 128-148. University of Arizona Press, Tucson.

2011a Mobility as Resistance: Colonialism among Nomadic Hunter-Gatherers in the American West. In Hunter-Gatherer Archaeology as Historical Process, edited by Kenneth E. Sassaman and Donald H. Holly, Jr., pp. 167-183. University of Arizona Press, Tucson. 2011b Obsidian Source Use in the Greater Yellowstone Area, Wyoming Basin, and Central Rocky Mountains. American Antiquity 76:372-394.

Schiffer, Michael B.

1986 Radiocarbon Dating and the "Old Wood" Problem: The Case of the Hohokam Chronology. Journal of Archaeological Science 13:13-30.

Smith, Craig S.

1992 The Fremont: A View from Southwest Wyoming. Utah Archaeology 1992:55-75.

Steward, Julian H.

1933 Ethnography of the Owens Valley Paiute. University of California Publications in American Archaeology and Ethnology No. 33, pp. 233-250. Berkeley, California.

Thomas, David H.

2014 Alta Toquima: Why Did Foraging Families Spend Summers at 11,000 Feet? In Archaeology in the Great Basin and Southwest, edited by Nancy J. Parezo and Joel C. Janetski, pp. 130-148. University of Utah Press, Salt Lake City.

Tuohy, Donald R.

1973 Nevada's Non-Ceramic Culture Sphere. Tebiwa 16:54-61.

Upham, Steadham

1994 Nomads of the Desert West: A Shifting Continuum in Prehistory. Journal of World Prehistory 8:113-167.

Wallinga, Jakob, Andrew Murray, and Ann Wintle

2000 The Single-Aliquot Regenerative-Dose (SAR) Protocol Applied to Coarse-Grain Feldspar. Radiation Measurements 32:529-533.

Wright, Gary A.

1978 The Shoshonean Migration Problem. Plains Anthropologist 23:113-137.

Submitted February 9, 2017; Revised May 16, 2017; Accepted May 24, 2017 